\title{
Lukasz Kutyło*
}

ORCID: 0000-0002-0499-1900

Uniwersytet Łódzki

\section{KRYZYS INSTYTUCJI RELIGIJNYCH I JEGO WPEYW NA RELIGIJNOŚĆ. PRZYPADEK POLSKI}

\begin{abstract}
Warto, by wśród pytań towarzyszących dzisiejszym dyskusjom podejmowanym na gruncie socjologii religii znalazły się te wprost nawiązujące do obserwowanego współcześnie kryzysu instytucji religijnych i jego wpływie na religijność. Z punktu widzenia teorii sekularyzacji ów kryzys pozostaje jednym z symptomów postępującego zeświecczenia i wynika z przeobrażeń strukturalnych zachodzących w społeczeństwie. Z kolei teorie ekonomiczne zakładają, że spowodowany jest niedopasowaniem „oferty” instytucji religijnych do potrzeb wiernych. W niniejszym artykule przyjąłem stanowisko pośrednie. Uznałem, że przeobrażenia strukturalne obniżają zdolność instytucji religijnych do organizacji życia religijnego, zwiększając tym samym niezadowolenie wiernych $\mathrm{z}$ ich funkcjonowania. To z kolei nie pozostaje bez wpływu na ich religijność. Główną konsekwencją tego kryzysu staje się bowiem spadek ich uczestnictwa w praktykach religijnych. By zweryfikować te przypuszczenia, oparłem się na danych dotyczących katolików z Polski, pochodzących z dwóch sondaży zrealizowanych w latach 1999 i 2008 w ramach Europejskiego Badania Wartości. Wyniki analizy statystycznej wydają się potwierdzać przyjęte założenia.
\end{abstract}

Słowa kluczowe: deinstytucjonalizacja, Kościół katolicki, religijność, sekularyzacja, Europejskie Badania Wartości

\section{WPROWADZENIE}

Punktem wyjścia dla rozważań uczyniłem słabnącą zdolność instytucji religijnych do organizacji życia religijnego wiernych. Zjawisko to obserwuje się między innymi w krajach Europy Zachodniej. Choć pierwotnie rozpatrywano je jako przejaw „europejskiej wyjątkowości”, to obecnie można je zauważyć także w innych kręgach kulturowych (np. w krajach arabskich) ${ }^{1}$. Przyczyn tego zjawiska upatruje się bądź w przemianach społecznych (jak ma to

* Łukasz Kutyło, Uniwersytet Łódzki, Wydział Ekonomiczno-Socjologiczny, Katedra Socjologii Polityki i Moralności, ul. Rewolucji 1905 r. 41/43, 90-214 Łódź; e-mail: lukasz.kutylo@uni.lodz.pl

1 Tak wynika między innymi z sondaży realizowanych w ramach Arab Barometer. W badanych krajach arabskich zaobserwowano spadek zaufania do partii muzułmańskich i liderów religijnych, a także wzrost odsetka osób określających siebie mianem niereligijnych i nieuczestniczących w praktykach religijnych. W największym stopniu zjawisko to dotyczyło ludzi młodych. W przypadku Tunezji, gdzie było ono najbardziej widoczne, odsetek osób określających siebie jako niereligijne wzrósł o 15 punktów procentowych (z 16\% w 2013 roku do $31 \%$ w 2019 roku). Zob. www.arabbarometer.org [10.02.2021]. 
miejsce w teoriach popytowych), bądź w rozdźwięku między „ofertą instytucji religijnych” a oczekiwaniami wiernych (jak dzieje się to w teoriach podażowych). W zależności od perspektywy teoretycznej zakłada się, że jego konsekwencją jest marginalizacja religijności bądź jej deinstytucjonalizacja.

Inspirując się tą dyskusją, przedmiotem analizy uczyniłem wpływ: (i) orientacji indywidualistycznej i zamożności (jako potencjalnych wskaźników świadczących o zachodzących przemianach społecznych), a także (ii) niezadowolenia z funkcjonowania instytucji religijnych na (iii) poziom religijności. Przyjąłem stanowisko pośrednie, wpisujące się w to, co określa się mianem tzw. teorii pomostowych (zob. Gaskins et al., 2013; Dhima i Golder, 2020), czerpiących zarówno z dorobku teorii popytowych, jak i podażowych. Uznałem, że postępującym zmianom społecznym towarzyszy zmiana oczekiwań części wiernych wobec instytucji religijnych. Jednak one bądź nie mogą wyjść naprzeciw tym oczekiwaniom, bądź też nie są tym zainteresowane. To zaś skutkuje wspomnianym rozdźwiękiem wpływającym na poziom religijności wiernych.

Empirycznej weryfikacji tego założenia dokonałem na podstawie danych pochodzących z dwóch sondaży zrealizowanych w ramach Europejskiego Badania Wartości (z lat 1999 oraz 2008). Analizą objąłem dane z Polski dotyczące tylko tych badanych, którzy deklarowali swoją przynależność do Kościoła katolickiego.

\section{FUNKCJONOWANIE INSTYTUCJI RELIGIJNYCH W ŚWIETLE TEORII POPYTOWYCH I PODAŻOWYCH}

Instytucje religijne pełnią istotną funkcję w obrębie tego, co Pierre Bourdieu określił mianem pola religijnego. W końcu to one w znacznej mierze odpowiadają za organizowanie religijności, jej instytucjonalizowanie (np. za utrwalanie właściwych dla danej religii wzorów zachowania) (Bourdieu, 1990, 2007). Teza o słabnącej zdolności instytucji religijnych do wypełniania tej funkcji jest szczególnie bliska teoriom sekularyzacji (teoriom popytowym). Chociaż straciły one dominującą pozycję w ramach socjologii religii, to jednak ignorowanie ich w dyskusji nad religijnością wydaje się nieuzasadnione. Przyjrzyjmy się wpierw, jak na interesujące nas zjawisko spogląda się właśnie z ich perspektywy.

W teoriach sekularyzacji przyjmuje się, że słabnąca zdolność instytucji religijnych do organizacji życia religijnego stanowi konsekwencję postępującego wraz z modernizacją procesu zeświecczenia. W Świętym baldachimie Peter Berger (2005) rozpatrywał zeświecczenie jako zjawisko, którego początków należałoby szukać u progu nowoczesności (chociaż jego korzenie tkwią głębiej, jeszcze w judaizmie). Biorąc pod uwagę przedstawioną przez niego koncepcję, z której założeń przynajmniej w części się potem wycofał, ta słabnąca zdolność do organizacji życia religijnego wynika z separacji kościołów od państwa, pozbawiającej instytucje religijne wielu funkcji. Ponadto istotny wpływ na to zjawisko ma pojawienie się dyskursów konkurencyjnych (np. naukowego, politycznego) wobec dyskursu religijnego, sprawiających, że wyjaśnienia religijne, dotychczas porządkujące wiedzę na temat świata, tracą na znaczeniu. Instytucje religijne, chcąc dostosować się do tych zmian, w tym do funkcjonowania w obrębie pluralistycznego społeczeństwa, stają się coraz bardziej świeckie. 
Podporządkowują się logice rynkowej, ulegając procesom profesjonalizacji i biurokratyzacji (zob. Zielińska, 2009).

Z kolei Thomas Luckmann, rozpatrując zjawisko zeświecczenia, wskazał, że przed naporem nowoczesności istniała spójność między religijnością indywidualną a oficjalnym modelem religii. Ten model to nic innego jak sposób organizacji życia religijnego, wytwarzany i utrwalany przez wyspecjalizowane do tego kościoły, a następnie przyswajany przez wiernych. Wysoki poziom stabilności tego „świętego kosmosu” zostaje zachowany tak długo, dopóki między pokoleniami nie istnieją znaczące różnice w warunkach życia, a także w zakresie doświadczanych przez nie problemów. Ta stabilność ulega zachwianiu, kiedy społeczeństwo zaczyna się gwałtownie przeobrażać. Instytucje religijne przestają wówczas nadążać za dokonującymi się zmianami, a ich zdolność do organizacji życia religijnego ulega osłabieniu (Luckmann, 2006).

$\mathrm{Na}$ istotną rolę tego, jak postępująca złożoność społeczeństwa wpływa na funkcjonowanie instytucji religijnych, zwracał też uwagę Niklas Luhmann. Twierdził bowiem, że sekularyzacja nie jest wyłącznie projektem politycznym ani zjawiskiem towarzyszącym przemianom społecznym, ale wynika z samej logiki systemu społecznego. Typowa dla nowoczesności dyferencjacja funkcjonalna wymusza niejako na instytucjach religijnych, by wycofały się do własnej niszy, oddając część ze swych dotychczasowych funkcji innym podsystemom społecznym. W wyniku tego procesu instytucje religijne zostają pozbawione możliwości dystrybucji niektórych społecznie pożądanych zasobów. Co więcej, ich zdolność do organizacji życia jednostek - wypełniających role w obrębie różnych podsystemów - maleje (Luhmann, 2007).

Dużym wyzwaniem dla teorii sekularyzacji stało się ożywienie religijne, przejawiające się między innymi w deprywatyzacji religijności (zob. Casanova, 2005). Doprowadziło ono do tego, że wskazane teorie utraciły swoją dominującą pozycję, a niektórzy z ich przedstawicieli (np. Berger czy Luckmann) zaczęli dystansować się od części swych poglądów (zob. Berger, 1999; Luckmann, 1990). Inni dalej jednak stoją na stanowisku, że teorie sekularyzacji są w stanie wyjaśniać zachodzące obecnie przemiany religijności. Takie podejście wydaje się właściwe między innymi dla Pippy Norris oraz Ronalda Ingleharta $(2006,2007)$ przyjmujących, że poziom religijności jest ściśle powiązany z poczuciem bezpieczeństwa. Ich zdaniem wiara odgrywa istotną rolę wszędzie tam, gdzie warunki życia są złe lub/i niestabilne. Zależności między religijnością a poziomem rozwoju społecznego nie należy jednak rozpatrywać w sposób liniowy i deterministyczny, gdyż nawet w zamożnych krajach zdarzają się okresy większego niepokoju skutkujące ożywieniem wiary. Wskazana relacja ma więc charakter probabilistyczny. Z zaproponowanego przez nich podejścia wynikają dwa wnioski, istotne w perspektywie podjętych tutaj rozważań. Po pierwsze, zdolność instytucji religijnych do organizacji życia religijnego wiernych słabnie w stabilnych czasach. Pewnym wyjaśnieniem tego zjawiska może być badanie zrealizowane przez Bena Gaskinsa, Matta Goldera oraz Dawida Siegela (2013), do którego będę się jeszcze odwoływał. Założono w nim, że dobra religijne i świeckie są względem siebie substytucyjne. W sytuacji gdy wzrasta możliwość uzyskania dóbr świeckich, spada zainteresowanie dobrami religijnymi (np. zbawieniem). Po drugie, uzależnienie religijności od bezpieczeństwa sprawia, że potrzeba wiary nigdy nie zaniknie, gdyż nie da się wyeliminować w pełni ryzyka (także w zamożnych krajach). Nie mówiąc już o tym, że sam rozwój wytwarza nowe zagrożenia. 
Niektórzy przedstawiciele teorii sekularyzacji są bardziej ofensywni w swych wnioskach. Ich zdaniem dane zbierane w Wielkiej Brytanii od połowy XIX wieku wyraźnie wskazują na to, że religijność słabnie i nie jest zastępowana przez to, co w literaturze przedmiotu określa się mianem „,nowej duchowości” czy „pozainstytucjonalnej religijności”. Parę lat temu rozgorzała na ten temat gorąca dyskusja, kiedy David Voas i Steve Bruce uczynili przedmiotem krytyki wyniki pochodzące z Kendal Project (zob. Heelas et al., 2005). Odtwarzając niegdysiejszy spór między funkcjonalistami a substancjalistami, stwierdzili, że przyjęta w nim definicja duchowości jest zbyt szeroka. Tym bardziej, że dla większości osób angażujących się w „duchowe aktywności” najważniejsze były motywacje zdrowotne, a typowe dla nich wzory zachowania nie ulegały transmisji pokoleniowej (Voas i Bruce, 2007). Zdaniem Bruce'a, instytucje religijne słabną, a deklarowaną przez Brytyjczyków wiarę w istnienie Boga bądź Siły Wyższej rządzącej światem należałoby traktować nie jako przejaw niezinstytucjonalizowanej religijności, ale raczej jako swego rodzaju przeświadczenie, uświadamiane incydentalnie i nierzadko wyabstrahowane z jakiejkolwiek tradycji religijnej. W związku z tym, w przypadku Wielkiej Brytanii można mówić jedynie o „,archipelagach religijności”, składających się głównie ze starszych kobiet, społeczności imigranckich (np. polskiej) czy wyizolowanych geograficznie zbiorowości protestanckich zamieszkujących Walię oraz Szkocję. Poza tymi „,archipelagami” religie ze swymi kodeksami stają się czymś kłopotliwym dla pluralistycznego, indywidualistycznie zorientowanego społeczeństwa. Tym zapewne można tłumaczyć fakt, że zjawisko konwersji religijnej wśród osób wychowanych w środowisku świeckim jest rzadkie² (Bruce, 2016; Bruce i Voas, 2010).

Przeciw takiej interpretacji przemian religijnych występują między innymi przedstawiciele związani z teorią podażową (ekonomiczną). Przyjmują, że teorie sekularyzacji opierają się nie tyle na naukowych, ile na mitologicznych założeniach. Na przykład Rodney Stark twierdzi, że przekonanie o kwitnącej w okresie przednowoczesnym religijności (poddanej następnie zeświecczeniu) wydaje się wątpliwe. Zaangażowanie religijne stanowi bowiem konsekwencję działalności instytucji religijnych, w odpowiedni sposób regulujących jednostkową aktywność i ukierunkowujących ją na wiarę. Do tego potrzebna jest zaś odpowiednia infrastruktura kościelna (Stark, 1999). Z perspektywy teorii podażowych słabnąca zdolność instytucji religijnych do organizacji życia religijnego, przejawiająca się przede wszystkim w spadku uczestnictwa w praktykach religijnych, wynika z rozdźwięku między „ofertą religijną” tych instytucji a oczekiwaniami wiernych. Ten rozdźwięk pojawia się przede wszystkim na rynkach monopolistycznych lub quasi-monopolistycznych, na których istnieje dominujący kościół, a jego dominacja bądź wynika z preferencyjnych regulacji prawnych (np. ograniczających innym podmiotom wejście na rynek religijny), bądź/i stanowi rezultat silnej pozycji opartej na tradycji. Presja na tego rodzaju dominujące instytucje, by zmieniały swe funkcjonowanie i dostosowywały się do nowych warunków społecznych, jest mniejsza od presji wywieranej na rynkach konkurencyjnych. W wyniku tego ulegają one „rozleniwieniu” skutkującemu

2 Bruce powołuje się tutaj między innymi na rezultaty Scottish Social Attitudes Survey z 2001 roku. Wynika z niego, że spośród osób wychowanych w środowisku świeckim (gdzie rodziców określono jako niereligijnych) tylko 5\% deklarowało przynależność do Kościoła bądź wspólnoty religijnej w życiu dorosłym (zob. Bruce i Glendinning, 2003). 
ostatecznie tym, że wierni zaczynają z nich „migrować”. Z kolei na rynkach konkurencyjnych słabnące instytucje są bardziej skłonne rewidować swoje funkcjonowanie, na przykład zmieniając „ofertę” bądź niszę na rynku religijnym. W innym przypadku tracą wiernych i znikają (Stark i Finke, 2000; Stark i Iannaccone, 1994, 1995). Teorie podażowe zakładają więc, że potrzeby religijne są na względnie stałym poziomie. Deinstytucjonalizacja świadczy zaś o nieefektywności instytucji religijnych, a dokładniej rzecz ujmując, o tym, że instytucje religijne nie są w stanie zaadaptować się do nowych okoliczności (zob. Stark i Smith 2010).

\section{PRZYPADEK KOŚCIOŁA KATOLICKIEGO W POLSCE}

Oba wspomniane nurty teoretyczne wyłoniły się w określonych kontekstach kulturowych. W tym sensie, że punktem wyjścia dla formułowanych na ich gruncie założeń były doświadczenia typowe dla Europy Zachodniej i Stanów Zjednoczonych. Powstaje pytanie, na ile przeświadczenie o słabnącej zdolności instytucji religijnych do organizacji życia religijnego pozostaje uzasadnione w odniesieniu do Polski? By na nie odpowiedzieć, w pierwszej kolejności warto skupić się na rezultatach sondaży opinii publicznej.

Z badań realizowanych przez CBOS wynika, że w ciągu trzynastu lat odsetek osób deklarujących się jako wierzące nie uległ istotnym zmianom. W latach 1997-2005 utrzymywał się na poziomie 96\%. W ostatnich latach nieznacznie, aczkolwiek systematycznie maleje. Najniższą wartość (91\%) wskaźnik ten osiągnął w 2020 roku. Od 2008 roku stabilny pozostaje zaś odsetek osób deklarujących się jako głęboko wierzące (8\%). Wzrasta natomiast odsetek Polaków, którzy są skłonni określać siebie mianem raczej lub całkowicie niewierzących. W 2007 roku było ich 4\%, a w 2019 - 8\%. Od 1997 roku daje się także zaobserwować spadek regularnego (tj. mającego miejsce przynajmniej raz w tygodniu) uczestnictwa w praktykach religijnych. Między 1997 a 2007 rokiem odsetek Polaków biorących w nich udział był ustabilizowany na poziomie 57-58\%. Następnie odsetek ten zaczął spadać, by znów się ustabilizować w latach 2013-2018 na poziomie 49-50\%. Za to w latach 2019-2020 wartość ta po raz kolejny spadła. Wynosi obecnie 47\% (a więc jest o 11 punktów procentowych niższa aniżeli wartość z 1997 roku). Bardziej ustabilizowany wydaje się odsetek osób biorących nieregularnie udział w praktykach religijnych. W latach 1997-2007 wynosił on 33-34\%. Od 2007 roku odsetek ten zaczął rosnąć. Swój szczyt osiągnął w 2017 roku, kiedy jego wartość wyniosła 39\%. W kolejnych latach dało się zaś zaobserwować nieznaczny, jednoprocentowy spadek liczby osób praktykujących nieregularnie. I wreszcie odsetek Polaków w ogóle niebiorących udziału w nabożeństwach utrzymywał się przez dłuższy czas (do 2009 roku) na tym samym poziomie. Wynosił 9-10\%. Następnie wahał się w granicach $12-13 \%$, by w latach 2019-2020 osiągnąć wartość 15\% (Komunikat CBOS nr 63, 2020).

Interesujących danych, dotyczących tym razem dominicantes, dostarczają badania realizowane przez Instytut Statystyki Kościoła Katolickiego (ISKK). Wskaźnik ten mierzony jest na podstawie bezpośredniego zliczania wiernych uczestniczących w nabożeństwach w trakcie jednej wybranej niedzieli w roku. Odzwierciedla on (w procentach) stosunek liczby wiernych biorących udział w mszy świętej do ogólnej liczby zobowiązanych do tego osób. 
ISKK dokonuje pomiarów od 1979 roku. Najwyższą wartość dominicantes zaobserwowano w 1987 roku (53,3\%), najniższą zaś w roku 2016 (36,7\%). Odsetek ten systematycznie maleje. W latach 80 . wynosił średnio - 51,6\%, w latach 90. - 46,8\%, w pierwszej dekadzie XXI wieku - 44,6\%, zaś w drugiej - 38,9\%. (zob. ISKK). Szczegółowe dane obrazujące wartość tego wskaźnika w latach 1980-2019 zostały przedstawione na rysunku 1.

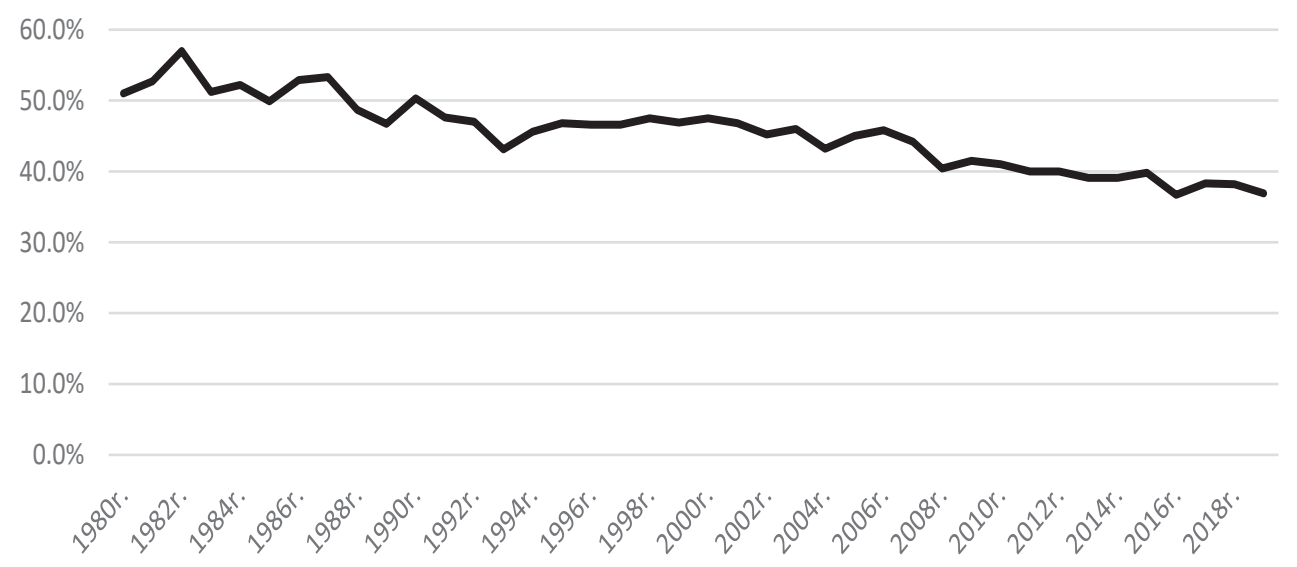

Rysunek 1. Wartości dotyczące liczby dominicantes w latach 1980-2019 [\%]

Źródło: na podstawie danych pochodzących z Instytutu Statystyki Kościoła Katolickiego (http://iskk.pl)

Dane te mogą sugerować, że w ostatnich dekadach słabnie zdolność Kościoła katolickiego w Polsce do organizacji życia religijnego przynajmniej części wiernych. Janusz Mariański, zastanawiając się nad tym rozdźwiękiem między odsetkiem osób deklarujących wiarę w Boga a odsetkiem regularnie uczestniczących w praktykach religijnych dochodzi do wniosku, że w polskim społeczeństwie zachodzi zjawisko deinstytucjonalizacji religijności. Przejawia się ona w wielu różnych formach, a indywidualne preferencje stają się ważniejsze od reguł narzuconych przez Kościół (Mariański, 2010, 2013). Jak pisze Mariański: „,[...] jednostki nie tyle przejmują pewien obowiązujący bezwzględnie model religijności oferowany przez »monopolistyczne« Kościoły, ile raczej konstruują własną strukturę pola religijnego, aż po religijność eremitów” (Mariański, 2008, s. 98). W innym zaś miejscu stwierdza: „Kościelne instytucje straciły monopol na określanie tego, co religijne. Przemiany religijności w ostatnich trzech dekadach można określić skrótowo jako odchodzenie od bezalternatywnego, ściśle zinstytucjonalizowanego, wiarygodnego modelu religijności kościelnej” (Mariański, 2004, s. 51).

Jednym z czynników przyczyniających się do tej dezinstytucjonalizacji jest postępująca indywidualizacja, towarzysząca przemianom społecznym. Z drugiej jednak strony, warto byłoby się zastanowić, jaką rolę w tym procesie odgrywa niezadowolenie z funkcjonowania Kościoła katolickiego. Sam Mariański dostrzega problem. Pisze bowiem: „Wiele wskazuje na to, że na przełomie pierwszej i drugiej dekady XXI wieku coraz wyraźniej rozpoczyna się 
powolny proces kryzys zaufania do Kościoła jako instytucji społecznej, a częściowo i moralnej” (Mariański, 2017, s. 84). Pojawiają się też negatywne opinie pod adresem Kościoła. Odnosząc się do nich Mariański, stwierdza: „Jeżeli nawet te opinie i poglądy, a nawet uprzedzenia, nie zawsze odzwierciedlają rzeczywisty obraz Kościoła, to nie są one bez znaczenia dla kształtowania się opinii o Kościele w całym społeczeństwie, bo jest on właśnie takim, jaki ludziom się wydaje. Część zdystansowanych katolików uważa, że Kościół katolicki nie daje odpowiedzi na pytania, które są dla nich w życiu ważne” (Mariański, 2017, s. 84-85).

Jeśli przedmiotem uwagi uczynimy rozdźwięk między „ofertą Kościoła” a oczekiwaniami wiernych, to interesującej wiedzy na ten temat dostarczają między innymi badania Józefa Baniaka zrealizowane wśród młodzieży w latach 2008-2011. Przedmiotem uwagi uczyniono w nich na przykład lęki przed Kościołem instytucjonalnym. Okazało się, że takie odczucia towarzyszyły aż 40,1\% respondentów. Jak pisze Baniak, większość tych lęków wywołuje sam Kościół, postrzegany przez młodzież jako „[...] instytucja konserwatywna i dogmatyczna, wpływająca destrukcyjnie na ich myślenie, wybory życiowe i decyzje, hierarchię wartości i sposób działania, hamująca ich dążenia i osiąganie celów życiowych” (Baniak, 2015, s. 34). Badana młodzież obawia się także języka, jakim posługuje się Kościół, nierzadko skomplikowanego, a nawet agresywnego, zwłaszcza wtedy, gdy instytucja ta wypowiada się ustami swych hierarchów w sprawach politycznych czy w kwestiach moralności. Respondentów niepokoi ponadto konserwatyzm religijny i moralny, odbiegający ich zdaniem od oczekiwań współczesnych ludzi, przejawiający się między innymi w upowszechnieniu niezrozumiałych dogmatów czy w ograniczaniu wolności religijnej (np. w podporządkowaniu religijności starym obrzędom i rytuałom). Konkludując, Baniak dochodzi do wniosku, że taka postawa Kościoła wzbudza lęk w młodych ludziach i ich od niego odciąga (Baniak, 2015, s. 34).

Na podobne zjawisko zwraca uwagę Maria Libiszowska-Żółtkowska. Na podstawie wyników badania zrealizowanego wśród studentów w 2010 roku dochodzi do wniosku, że choć Kościół jest doceniany za rolę, jaką odgrywa w podtrzymywaniu tożsamości narodowej, to zarazem jest krytykowany za zaangażowanie polityczne czy nadmierne ingerowanie w sprawy, które postrzegane są jako prywatne czy intymne (np. te związane z seksualnością). To sprawia, że Kościół traci autorytet wśród młodzieży akademickiej. Jak jednak dodaje Libiszowska-Żółtkowska: „Młodzi odchodzą nie tyle od Boga, co od wzorca propagowanego przez kościelne instytucje. Religijność młodzieży polega coraz częściej na duchowości poza Kościołem" (Libiszowska-Żółtkowska, 2010, s. 134).

Biorąc pod uwagę wyniki pochodzące z zaprezentowanych powyżej badań, można stwierdzić, że przeświadczenie o słabnącej zdolności Kościoła do organizacji życia religijnego wiernych jest przynajmniej w części uzasadnione. Rozważając mechanizm przyczynowy kryjący się za tym zjawiskiem należałoby przyjąć, że przemianom społecznym (przejawiającym się między innymi w indywidualizacji systemów wartości i wzroście zamożności) towarzyszy zmiana oczekiwań wobec Kościoła jako instytucji. Kościół, nie mogąc bądź nie chcąc wyjść im naprzeciw, wytwarza sytuację „rozdźwięku”, odciskającą swe piętno na poziomie religijności. Jeśli rzeczywiście tak jest, to powinniśmy zaobserwować następującą zależność:

Hipoteza badawcza: Orientacja indywidualistyczna, zamożność oraz niezadowolenie z funkcjonowania Kościoła w istotny statystycznie sposób wpływają na poziom religijności. 


\section{METODA}

\section{POPULACJA}

Aby zweryfikować hipotezę, skorzystałem z danych pochodzących z sondaży realizowanych w ramach Europejskiego Badania Wartości (z lat 1999 oraz 2008) (zob. Europejskie Badanie Wartości). Analizą objąłem wskazania badanych z Polski (w wieku powyżej 18 lat), deklarujących swoją przynależność do Kościoła katolickiego. W sondażu z 1999 roku ogółem było 1029 takich osób (na 1095 respondentów, którzy brali udział w sondażu), zaś w sondażu z 2008 roku - 1382 (na 1510 respondentów, którzy uczestniczyli w badaniu).

Analizę próbowałem rozszerzyć o dane pochodzące z ostatniego sondażu, zrealizowanego w 2017 roku. Niestety, okazało się to niemożliwe. W dostępnej bazie dalej brakuje bowiem niektórych danych, co uniemożliwiło między innymi opracowanie wskaźnika mierzącego poziom niezadowolenia z funkcjonowania Kościoła. Uznałem jednak, że oparcie się na danych z dwóch wymienionych badań powinno pozwolić - w razie potwierdzenia hipotezy badawczej - na ukazanie interesującego mnie mechanizmu przyczynowego.

\section{OPERACJONALIZACJA POJEĆ́}

Na potrzeby analizy danych konieczna stała się operacjonalizacja następujących pojęć: (a) poziomu religijności; (b) niezadowolenia z funkcjonowania Kościoła; (c) orientacji indywidualistycznej; oraz (d) poziomu zamożności.

Poziom religijności. Skalę do pomiaru tej zmiennej stworzyłem, opierając się na pięciu pytaniach, w których badani mieli: (1) zdeklarować swoją religijność oraz (2) wiarę w osobowego Boga; (3) zdefiniować, jak bardzo Bóg jest ważny w ich życiu; (4) określić, jak często modlą się i (5) uczestniczą w mszach świętych. Ze względu na to, że ten wybór był arbitralny, ważne wydają się pewne wyjaśnienia, tłumaczące przyjęte tutaj podejście. Po pierwsze, uznałem, że pytania te dość dobrze odzwierciedlają dwa wymiary religijności (obok deklarowanej przynależności do Kościoła, który to wymiar został przyjęty na wstępie i posłużył do zdefiniowania badanej populacji): wiarę oraz sposoby jej praktykowania. Po drugie, istniała możliwość, aby rozbudować ten wskaźnik o dodatkowe pytania, odnoszące się między innymi do wiary badanych w niebo, piekło, grzech itd. Wydało mi się to jednak nieuzasadnione. Uwzględnienie ich mogłoby bowiem spowodować, że nadmiernie skupiłbym się na kwestiach związanych z wiarą, nie doceniając tym samym zagadnień dotyczących praktykowania religijności. Pewnym rozwiązaniem tego dylematu, na które się ostatecznie nie zdecydowałem, byłoby stworzenie wag. Po trzecie, wskazane pytania opierały się na różnych skalach. Niektóre z nich były dychotomiczne, inne zaś znacznie bardziej złożone (np. 10-stopniowe). Wymagało to ode mnie ich standaryzacji. Ostatecznie, analizując rozkłady odpowiedzi na te pytania, każdą z tych skal sprowadziłem do skali dychotomicznej. Założyłem przy tym, że wartość 1 zostanie przypisana respondentowi, gdy: określił siebie mianem osoby religijnej, zadeklarował wiarę w osobowego Boga, co najmniej raz w tygodniu modlił się i uczestniczył w mszy świętej, a także stwierdził, że Bóg jest ważny w jego życiu (wskazał wartość 8 bądź większą na 10-stopniowej skali). 
Skonstruowana w ten sposób skala okazała się rzetelna. Wartości współczynnika alfa Cronbacha wyniosły odpowiednio: $\alpha=0,684$ dla danych z 1999 roku oraz $\alpha=0,689$ dla danych z roku 2008. Przedmiotem analizy objąłem średnią wartość wskazań badanego, mieszczącą się w przedziale od 0 do 1 . Im była ona wyższa, tym bardziej był on religijny.

Niezadowolenie z funkcjonowania Kościoła. Skala do pomiaru tej zmiennej opierała się na jednym pytaniu obecnym w obu sondażach. Badany, korzystając ze skali dychotomicznej, miał się w nim ustosunkować do tego, czy Kościół katolicki w Polsce daje właściwe odpowiedzi na kwestie odnoszące się do: (a) moralnych problemów i potrzeb jednostki; (b) problemów życia rodzinnego; (c) duchowych potrzeb człowieka; (d) problemów społecznych i politycznych ważnych obecnie dla kraju. Podobnie jak w poprzednim przypadku, budowa wskaźnika na podstawie tak sformułowanych zagadnień może wydać się wątpliwa. W końcu, brakuje w nim odniesień na przykład do organizacji życia parafialnego czy jakości duszpasterstwa. Uznałem jednak, że przyjęte tutaj podejście jest właściwe. Istnieje bowiem przypuszczenie, że ustosunkowując się do tych zagadnień badani pośrednio wyrażali swoją opinię także na te kwestie, które zostały w pytaniu pominięte.

Opracowana w ten sposób skala okazała się rzetelna. Wartości współczynnika alfa Cronbacha wyniosły odpowiednio: $\alpha=0,824$ dla danych z 1999 roku oraz $\alpha=0,775$ dla danych z 2008 roku. Przedmiotem analizy objąłem ostatecznie średnią wartość wskazań respondenta, mieszczącą się w przedziale od 0 do 1 . Im była ona wyższa, w tym większym stopniu pozostawał on niezadowolony z funkcjonowania Kościoła.

Orientacja indywidualistyczna. W przypadku tej zmiennej przedmiotem mojego zainteresowania był indywidualizm w zakresie wartości (por. Kopka, 2014). Przez to pojęcie rozumiem orientację przywiązującą dużą wagę do wolności indywidualnej (wolności negatywnej w rozumieniu, jakie temu pojęciu nadali John S. Mills czy Isaiah Berlin), zakładającej, że jednostkowe wybory powinny być względnie niezależne od presji grupy czy zobowiązań płynących z tradycji. Orientacja ta, wynikająca z postępującej złożoności społeczeństwa i obecności w nim wielu różnych ładów normatywnych, opiera się między innymi na przeświadczeniu, że w przestrzeni społecznej dopuszczalne są wzory zachowania, które przez nas samych mogą być nieakceptowane (np. których sami nigdy byśmy nie realizowali). Aby móc dokonać jej pomiaru, odwołałem się do pytania, w którym respondent wyrażał swoją opinię na temat wybranych zachowań. Posługiwał się przy tym skalą 10-stopniową, której skrajne pozycje odzwierciedlały następujące stanowiska: „dane zachowanie nigdy nie może być usprawiedliwione” oraz „zawsze można je usprawiedliwić”. Uwagę skupiłem na pięciu pozycjach zawartych w tym pytaniu. Odnosiły się one do takich zachowań, jak: zażywanie miękkich narkotyków (marihuany, haszyszu), homoseksualizm, przerywanie ciąży, rozwód, eutanazja.

Opracowana na podstawie tych pozycji skala okazała się rzetelna. Wartości współczynnika alfa Cronbacha wyniosły odpowiednio: $\alpha=0,775$ dla danych z 1999 roku oraz $\alpha=0,817$ dla danych z 2008 roku. Przedmiotem analizy uczyniłem średnią wartość ze wskazań badanego, mieszczącą się w przedziale od 0 do 1 . Im była ona wyższa, w tym większym stopniu cechowała go orientacja indywidualistyczna.

Poziom zamożności. Założyłem, że wartość tej zmiennej będzie odzwierciedlać stosunek dochodu uzyskiwanego przez gospodarstwo domowe, w ramach którego funkcjonuje 
respondent, do liczby osób to gospodarstwo tworzących. Jej operacjonalizacja okazała się utrudniona, głównie z tego powodu, że w obu sondażach zastosowano odmienne sposoby jej kategoryzowania (co jest zrozumiałe, w końcu oba sondaże dzieli niemal dziesięć lat). Przewidziano jednak tego rodzaju kłopoty i w obu bazach danych uwzględniono zmienną wystandaryzowaną, w taki sposób porządkującą zamożność, że dało się wyodrębnić respondentów: niezamożnych, umiarkowanie zamożnych oraz zamożnych. Podejście to znalazło zastosowanie w niniejszej analizie.

\section{ANALIZA DANYCH}

$\mathrm{Na}$ wstępie uwagę skupiłem na opisie statystycznym zmiennych. Następnie opracowałem dwa modele regresji liniowej wielorakiej. Jeden z nich dotyczył danych z roku 1999, a drugi z 2008. W obu zmienną objaśnianą był poziom religijności, a zmiennymi objaśniającymi takie zmienne, jak: niezadowolenie z funkcjonowania instytucji religijnych, orientacja indywidualistyczna, poziom zamożności. W obu modelach uwzględniłem też trzy zmienne demograficzne, w tym: płeć (kobieta) (zmienna ilościowa, dychotomiczna) ${ }^{3}$, wiek, a także wiek, w jakim respondent zakończył edukację (zmienna ilościowa odzwierciedlająca w sposób przybliżony poziom jego wykształcenia). Zanim przystąpiłem do modelowania, skorelowałem ze sobą wszystkie zmienne objaśniające. Analizą objąłem tutaj wartości współczynnika korelacji $r$ Pearsona. Następnie przeszedłem do modelowania. W procesie tym zastosowałem metodę eliminacji wstecznej (opierającą się na pozbyciu się z modelu tych zmiennych, które nie wpływają istotnie na wartość zmiennej objaśnianej). Ostatecznie przedmiotem uwagi uczyniłem: stopień dopasowania obu modelów do danych oraz wartości współczynnika beta (wartości wystandaryzowane). Wszystkie analizy zrealizowałem w programie IBM SPSS.

\section{WYNIKI}

Przyjrzyjmy się zatem bliżej uzyskanym wynikom. W pierwszej kolejności warto skupić się na opisie wartości zmiennych uwzględnionych następnie w obu modelach. Jak wynika z tabeli 1, wartość wskaźnika poziom religijności wyniosła w 1999 roku 0,82, zaś w 2008 0,78. Podobnie jak w sondażach CBOS, dało się zaobserwować rozdźwięk między deklaracjami wiary a praktykowaniem religijności. Z danych za rok 1999 wynika, że 97,2\% badanych katolików określała siebie mianem religijnych, a 85,7\% deklarowało wiarę w osobowego Boga. Dla 76,0\% respondentów Bóg był ważny bądź bardzo ważny w ich życiu. Co najmniej raz w tygodniu modliło się $81,6 \%$ badanych, a $62,0 \%$ regularnie brało udział we mszy świętej. Z kolei w 2008 roku mianem osób religijnych określiło się 88,4\% badanych. Zdecydowana większość z nich (83,3\%) zadeklarowała wiarę w osobowego Boga. Dla 69,8\% Bóg był ważny bądź bardzo ważny w ich życiu. Co najmniej raz w tygodniu modliło się 74,4\% respondentów, a 55,5\% regularnie brało udział w mszy świętej.

\footnotetext{
3 Gdzie wartość 0 odpowiadała respondentowi mężczyźnie, a 1 respondentce kobiecie.
} 
Tabela 1. Wartości poszczególnych zmiennych uwzględnionych w obu modelach (lata 1999 i 2008)

\begin{tabular}{|c|c|c|}
\hline Nazwa zmiennej & Rok 1999 & Rok 2008 \\
\hline Poziom religijności (0-1) & 0,82 & 0,78 \\
\hline \multicolumn{3}{|c|}{ Wartości szczegółowe [\%] } \\
\hline Deklarowana religijność & 97,2 & 88,4 \\
\hline Wiara w osobowego Boga & 85,7 & 83,3 \\
\hline Ważność Boga w życiu & 76,0 & 69,8 \\
\hline Modlitwa (co najmniej $1 \mathrm{w}$ tyg.) & 81,6 & 74,4 \\
\hline Udział w mszy świętej & 62,0 & 55,5 \\
\hline Niezadowolenie z Kościoła (0-1) & 0,35 & 0,41 \\
\hline \multicolumn{3}{|c|}{ Wartości szczegółowe [\%] } \\
\hline Problemy moralne & 26,6 & 33,5 \\
\hline Problemy życiowe rodzin & 28,9 & 39,1 \\
\hline Potrzeby duchowe & 13,3 & 17,5 \\
\hline Problemy społeczne & 45,4 & 55,4 \\
\hline Orientacja indywidualistyczna $(1-10)$ & 0,30 & 0,31 \\
\hline \multicolumn{3}{|c|}{ Wartości szczegółowe ['średnia arytmetyczna; 1-10] } \\
\hline Miękkie narkotyki & 1,36 & 1,98 \\
\hline Homoseksualizm & 2,75 & 2,78 \\
\hline Przerywanie ciąży & 3,46 & 3,24 \\
\hline Rozwód & 4,49 & 4,40 \\
\hline Eutanazja & 3,18 & 3,29 \\
\hline \multicolumn{3}{|l|}{ Poziom zamożności } \\
\hline Niezamożni & 43,7 & 37,1 \\
\hline Umiarkowanie zamożni & 41,5 & 34,8 \\
\hline Zamożni & 14,8 & 28,1 \\
\hline \multicolumn{3}{|l|}{ Zmienne demograficzne } \\
\hline Kobiety & 55,2 & 56,5 \\
\hline Mężczyźni & 44,8 & 43,5 \\
\hline \multicolumn{3}{|c|}{ Wartości szczegółowe [średnia arytmetyczna] } \\
\hline Wiek & 48 & 45 \\
\hline Wiek ukończenia edukacji & 18 & 20 \\
\hline
\end{tabular}

Źródło: na podstawie danych pochodzących z Europejskiego Badania Wartości (sondaże z lat 1999 i 2008) 
W 1999 roku wartość wskaźnika niezadowolenie z funkcjonowania Kościoła wyniosła 0,35, zaś w 2008 roku - 0,41. Jeśli przyjrzymy się danym szczegółowym, to w obu sondażach badani byli najbardziej niezadowoleni z tego, w jaki sposób Kościół reaguje na problemy społeczne. W 1999 roku 45,5\% respondentów stwierdziło, że Kościół nie potrafi właściwie na nie odpowiedzieć. Zaś w 2008 roku taką opinię wyraziło 55,4\% badanych. Z kolei w największym stopniu docenione zostały działania Kościoła na rzecz potrzeb duchowych wiernych. W 1999 roku tylko 13,3\% respondentów uważało, że Kościół nie potrafi ich zaspokoić. W 2008 roku zaś - 17,5\%

W 1999 roku wartość wskaźnika orientacja indywidualistyczna wyniosła - 0,30, zaś w 2008 roku - 0,31. W obu sondażach akceptacja dla wymienionych zachowań była niska. Jeśli przyjrzymy się danym szczegółowym, to w 1999 roku poziom przyzwolenia - mierzony na 10-stopniowej skali - wyniósł w przypadku: miękkich narkotyków - 1,36, homoseksualizmu $-2,75$, przerywania ciąży $-3,46$, eutanazji $-3,18$. Jedynym wyjątkiem wydaje się względna akceptacja dla rozwodów $(4,49)$. Z podobną sytuacją mamy do czynienia w 2008 roku. Poziom przyzwolenia dla poszczególnych, wymienionych wcześniej zachowań był następujący w przypadku: miękkich narkotyków - 1,98, homoseksualizmu $-2,78$, przerywania ciąży - 3,24, eutanazji - 3,29. Podobnie jak wyżej, w większym stopniu akceptowano rozwody $(4,40)$.

Między rokiem 1999 a 2008 wzrosła zamożność Polaków. Z danych Banku Światowego wynika, że w 1999 roku wartość PKB per capita w przeliczeniu na jednego mieszkańca wyniosła 8088 dolarów, zaś w 2008 - już 11798 dolarów. Przy uwzględnieniu parytetu siły nabywczej wskaźnik ten przyjął następujące wartości: 15435 dolarów w 1999 roku oraz 22516 dolarów w 2008 roku. Znalazło to odzwierciedlenie w strukturze zamożności respondentów. W 1999 roku 42,8\% z nich zostało zakwalifikowanych jako osoby z niezamożnych gospodarstw domowych, a tylko 14,5\% jako osoby z gospodarstw zamożnych. Nieco odmienna sytuacja miała miejsce w 2008 roku. Respondentów z niezamożnych gospodarstw domowych było $37,1 \%$, a z zamożnych - 28, $1 \%$

Następnie, by przygotować modele regresji liniowej, skorelowałem ze sobą zmienne objaśniające. W przypadku danych pochodzących z sondażu z 1999 roku okazało się, że istnieje silna i istotnie statystyczna zależność między niezadowoleniem z funkcjonowania Kościoła a orientacją indywidualistyczna $(r=0,51 ; p<0,001)$. Ponadto udało się zaobserwować kilka innych relacji między zmiennymi, choć zależności te były już bardziej umiarkowane. Z punktu widzenia podjętej $\mathrm{w}$ artykule problematyki, interesujące wydają się zależności między niezadowoleniem z funkcjonowania Kościoła a: wiekiem $(r=-0,30 ; p<0,001)$ oraz wiekiem, w którym respondent zakończyt edukację $(r=0,26 ; p<0,001)$. Udało się także zidentyfikować zależności między orientacją indywidualistyczna a: wiekiem badanego $(r=-0,31 ; p<0,001)$ i wiekiem, w jakim zakończyt on edukację $(r=0,29 ; p<0,001)$. Upraszczając: z danych wynika, że niezadowolenie z Kościoła istotnie łączyło się z orientacją indywidualistyczną, młodszym wiekiem oraz lepszym wykształceniem. Szczegółowe rezultaty korelacji zostały przedstawione w tabeli 2 .

Z danych pochodzących z 2008 roku wynikają podobne zależności, choć ich siła jest już wyraźnie mniejsza. Udało się zatem zaobserwować umiarkowaną korelację między niezadowoleniem z funkcjonowania Kościoła a orientacją indywidualistyczna $(r=0,31 ; p<0,001)$. 
Ponadto okazało się, że istnieją słabe, aczkolwiek statystycznie istotne, zależności: między niezadowoleniem z funkcjonowania Kościoła a wiekiem badanego $(r=-0,17 ; p<0,001)$ i wiekiem, w jakim zakończył on edukację $(r=0,13 ; p<0,001)$, a także między orientacja indywidualistyczna a poziomem zamożności $(r=0,14 ; p<0,001)$, wiekiem badanego $(r=-0,19$; $p<0,001)$ oraz wiekiem, $w$ jakim zakończyt edukacje $(r=0,14 ; p<0,001)$. Szczegółowe wyniki korelacji tych zmiennych zostały przedstawione w tabeli 3 .

Tabela 2. Wyniki korelacji zmiennych objaśniających (1999 rok)

\begin{tabular}{|l|c|c|c|c|c|c|}
\hline \multicolumn{1}{|c|}{ Zmienne } & $\begin{array}{c}\text { Niezado- } \\
\text { wolenie } \\
\text { z KK }\end{array}$ & $\begin{array}{c}\text { Orientacja } \\
\text { indywi- } \\
\text { dualistyczna }\end{array}$ & $\begin{array}{c}\text { Poziom } \\
\text { zamożno- } \\
\text { ści }\end{array}$ & $\begin{array}{c}\text { Płeć } \\
\text { (kobieta) }\end{array}$ & Wiek & $\begin{array}{c}\text { Wiek } \\
\text { ukończenia } \\
\text { edukacji }\end{array}$ \\
\hline $\begin{array}{l}\text { Niezadowolenie } \\
\text { z KK }\end{array}$ & 1 & $0,51^{*}$ & $0,14^{*}$ & $-0,05$ & $-0,30^{*}$ & $0,26^{*}$ \\
\hline $\begin{array}{l}\text { Orientacja } \\
\text { indywidualistyczna }\end{array}$ & $0,51^{*}$ & 1 & $0,14^{*}$ & 0,04 & $-0,31^{*}$ & $0,29 *$ \\
\hline $\begin{array}{l}\text { Poziom } \\
\text { zamożności }\end{array}$ & $0,14^{*}$ & $0,14^{*}$ & 1 & $-0,06$ & $-0,17^{*}$ & $0,30^{*}$ \\
\hline Płeć (kobieta) & $-0,05$ & 0,04 & $-0,06$ & 1 & 0,06 & $-0,01$ \\
\hline Wiek & $-0,30^{*}$ & $-0,31^{*}$ & $-0,17^{*}$ & 0,06 & 1 & $-0,44^{*}$ \\
\hline $\begin{array}{l}\text { Wynik ukończenia } \\
\text { edukacji }\end{array}$ & $0,26^{*}$ & $0,29 *$ & $0,30^{*}$ & $-0,01$ & $-0,44^{*}$ & 1 \\
\hline
\end{tabular}

* gdy $p<0,05$

Źródło: na podstawie danych pochodzących z Europejskiego Badania Wartości (sondaż z 1999 roku)

Tabela 3. Wyniki korelacji zmiennych objaśniających (2008 rok)

\begin{tabular}{|l|c|c|c|c|c|c|}
\hline \multicolumn{1}{|c|}{ Zmienne } & $\begin{array}{c}\text { Niezado- } \\
\text { wolenie } \\
\text { z KK }\end{array}$ & $\begin{array}{c}\text { Orientacja } \\
\text { indywi- } \\
\text { dualistyczna }\end{array}$ & $\begin{array}{c}\text { Poziom } \\
\text { zamożno- } \\
\text { ści }\end{array}$ & $\begin{array}{c}\text { Pleć } \\
\text { (kobieta) }\end{array}$ & Wiek & $\begin{array}{c}\text { Wiek } \\
\text { ukończenia } \\
\text { edukacji }\end{array}$ \\
\hline $\begin{array}{l}\text { Niezadowolenie } \\
\text { z KK }\end{array}$ & 1 & $0,31^{*}$ & $-0,01$ & $-0,03$ & $-0,17^{*}$ & $0,13^{*}$ \\
\hline $\begin{array}{l}\text { Orientacja } \\
\text { indywidualistyczna }\end{array}$ & $0,31^{*}$ & 1 & $0,14^{*}$ & 0,02 & $-0,19^{*}$ & $0,14^{*}$ \\
\hline $\begin{array}{l}\text { Poziom } \\
\text { zamożności }\end{array}$ & $-0,01$ & $0,14^{*}$ & 1 & $-0,02$ & $-0,33^{*}$ & $0,28^{*}$ \\
\hline Płeć (kobieta) & $-0,03$ & 0,02 & $-0,02$ & 1 & 0,01 & 0,01 \\
\hline Wiek & $-0,17^{*}$ & $-0,19^{*}$ & $-0,33^{*}$ & 0,01 & 1 & $-0,46^{*}$ \\
\hline $\begin{array}{l}\text { Wiek ukończenia } \\
\text { edukacji }\end{array}$ & $0,13^{*}$ & $0,14^{*}$ & $0,28^{*}$ & 0,01 & $-0,46^{*}$ & 1 \\
\hline
\end{tabular}

* gdy $p<0,05$

Źródło: na podstawie danych pochodzących z Europejskiego Badania Wartości (sondaże z 2008 roku) 
Warto wreszcie skupić się na wynikach modelowania poziomu religijności. Model z 1999 roku okazał się stosunkowo dobrze dopasowany do danych (jak na badanie socjologiczne). Wartość skorygowanego współczynnika determinacji wyniosła bowiem $R^{2}=0,32$. Model wyjaśnia więc 32\% wariancji zmiennej objaśnianej. Spośród uwzględnionych w nich zmiennych największy wpływ na poziom religijności miało niezadowolenie z funkcjonowania Kościoła $(\beta=-0,38 ; p<0,001)$. Poza tym, na wartość zmiennej objaśnianej oddziaływała orientacja indywidualistyczna badanego $(\beta=-0,22 ; p<0,001)$ oraz jego bycie kobieta $(\beta=0,22$; $p<0,001)$.

Podobna sytuacja miała miejsce w przypadku modelu opierającego się na danych z 2008 roku. Jego wartość predykcyjna okazała się jednak słabsza. Wartość skorygowanego współczynnika determinacji wyniosła bowiem $R^{2}=0,27$. Oznacza to, że model wyjaśnia $27 \%$ wariancji poziomu religijności. Spośród uwzględnionych w nim zmiennych największy wpływ na zmienną objaśnianą miało niezadowolenie z funkcjonowania Kościoła $(\beta=-0,31$; $p<0,001)$. Liczba zmiennych oddziałujących na poziom religijności okazała się jednak większa niż w przypadku danych z 1999 roku i obejmowała: orientację indywidualistycz$n a(\beta=-0,16 ; p<0,001)$, bycie kobieta $(\beta=0,15 ; p<0,001)$, wiek badanego $(\beta=0,20$; $p<0,001)$ oraz wiek, $w$ jakim zakończyt on edukację $(\beta=-0,07 ; p<0,05)$.

Z pierwszego modelu wynika, że im bardziej badany był niezadowolony z funkcjonowania Kościoła, a także w im większym stopniu cechowała go orientacja indywidualistyczna, tym bardziej religijność słabła. Ponadto okazało się, że bycie kobietą zwiększa prawdopodobieństwo bycia osobą religijną. Podobne wnioski płyną z drugiego modelu. Religijność słabnie wraz z rosnącym niezadowoleniem z Kościoła oraz z pogłębianiem się orientacji indywidualistycznej. Ponadto, prawdopodobieństwo bycia religijnym maleje w przypadku mężczyzn, osób młodych oraz - nieznacznie - w sytuacji, gdy osoba poświęciła więcej czasu na naukę. Wyniki modelowania przedstawiłem w tabelach nr 4 i 5.

Tabela 4. Wyniki modelowania poziomu religijności (na podstawie danych z 1999 roku).

\begin{tabular}{|l|c|c|c|c|c|c|c|c|c|c|c|c|}
\hline \multirow{2}{*}{ Predyktory } & \multicolumn{3}{|c|}{ Model I } & \multicolumn{3}{c|}{ Model II } & \multicolumn{3}{c|}{ Model III } & \multicolumn{3}{c|}{ Model IV } \\
\cline { 2 - 13 } & B & SE & Beta & B & SE & Beta & B & SE & Beta & B & SE & Beta \\
\hline Stała & 0,86 & 0,07 & & 0,86 & 0,07 & & 0,85 & 0,05 & & 0,81 & 0,03 & \\
\hline $\begin{array}{l}\text { Niezadowolenie } \\
\text { z KK }\end{array}$ & $-0,27$ & 0,03 & $-0,38^{*}$ & $-0,27$ & 0,03 & $-0,38^{*}$ & $-0,27$ & 0,03 & $-0,38^{*}$ & $-0,26$ & 0,03 & $-0,38^{*}$ \\
\hline $\begin{array}{l}\text { Orientacja indy- } \\
\text { widualistyczna }\end{array}$ & $-0,31$ & 0,06 & $-0,23^{*}$ & $-0,31$ & 0,06 & $-0,23^{*}$ & $-0,31$ & 0,06 & $-0,24 *$ & $-0,30$ & 0,05 & $-0,22^{*}$ \\
\hline $\begin{array}{l}\text { Poziom } \\
\text { zamożności }\end{array}$ & $-0,01$ & 0,01 & $-0,01$ & - & - & - & - & - & - & - & - & - \\
\hline Płeć (kobieta) & 0,11 & 0,02 & $0,22 *$ & 0,11 & 0,02 & $0,22^{*}$ & 0,11 & 0,02 & $0,22^{*}$ & 0,11 & 0,02 & $0,22^{*}$ \\
\hline Wiek & $-0,01$ & 0,01 & $-0,05$ & $-0,01$ & 0,01 & $-0,05$ & $-0,01$ & 0,01 & $-0,05$ & - & - & - \\
\hline $\begin{array}{l}\text { Wiek ukończe- } \\
\text { nia edukacji }\end{array}$ & $-0,01$ & 0,01 & $-0,01$ & $-0,01$ & 0,01 & $-0,01$ & - & - & - & - & - & - \\
\hline
\end{tabular}

Legenda: *gdzie $p<0,05$.

Źródło: na podstawie danych pochodzących z Europejskiego Badania Wartości (1999 rok) 
Kryzys instytucji religijnych i jego wpływ na religijność. Przypadek Polski

Tabela 5. Wyniki modelowania poziomu religijności (na podstawie danych z 2008 roku)

\begin{tabular}{|l|c|c|c|c|c|c|}
\hline \multirow{2}{*}{ Predyktory } & \multicolumn{3}{|c|}{ Model I } & \multicolumn{3}{c|}{ Model II } \\
\cline { 2 - 7 } & B & SE & Beta & B & SE & Beta \\
\hline Stała & 0,71 & 0,07 & - & 0,74 & 0,07 & - \\
\hline Niezadowolenie z KK & $-0,25$ & 0,03 & $-0,31^{*}$ & $-0,25$ & 0,03 & $-0,31^{*}$ \\
\hline $\begin{array}{l}\text { Orientacja indywiduali- } \\
\text { styczna }\end{array}$ & $-0,25$ & 0,05 & $-0,17^{*}$ & $-0,24$ & 0,05 & $-0,16^{*}$ \\
\hline Poziom zamożności & 0,01 & 0,01 & 0,04 & - & - & - \\
\hline Płeć (kobieta) & 0,08 & 0,02 & $0,15^{*}$ & 0,08 & 0,02 & $0,15^{*}$ \\
\hline Wiek & 0,01 & 0,01 & $0,21^{*}$ & 0,01 & 0,01 & $0,20^{*}$ \\
\hline $\begin{array}{l}\text { Wiek ukończenia } \\
\text { edukacji }\end{array}$ & $-0,01$ & 0,01 & $-0,08^{*}$ & $-0,01$ & 0,01 & $-0,07^{*}$ \\
\hline
\end{tabular}

Legenda: *-gdzie $p<0,05$.

Źródło: na podstawie danych pochodzących z Europejskiego Badania Wartości (2008 rok)

Podsumowując wyniki badania, zarówno niezadowolenie z funkcjonowania Kościoła, jak i orientacja indywidualistyczna istotnie wpływają na poziom religijności. Taka sytuacja miała miejsce w przypadku danych z 1999 i z 2008 roku. Wśród zmiennych objaśniających istotnie oddziałujących na poziom religijności zabrakło jednak zamożności. Należy więc uznać, że hipotezę udało się pozytywnie zweryfikować tylko częściowo.

\section{DYSKUSJA}

Interpretując wyniki analiz, należałoby stwierdzić, że istnienie rozważanego przeze mnie mechanizmu przyczynowego jest prawdopodobne. Zarazem jednak jego obecność rodzi pewne problemy, dotychczas nie podjęte w artykule.

Jak wspomniałem, przeświadczenie o słabnącej zdolności Kościoła w Polsce jest tylko w części prawdziwe. Wydaje się bowiem, że poza zjawiskiem deinstytucjonalizacji, za które częściowo odpowiada zaobserwowany mechanizm przyczynowy, dalej mamy do czynienia ze sporym segmentem wiernych, których życie religijne jest skutecznie organizowane w ramach Kościoła. Świadczy o tym między innymi stosunkowo wysoki odsetek polskich katolików regularnie biorących udział w mszach świętych czy też ustabilizowana grupa wiernych, której przedstawiciele określają siebie mianem osób „głęboko wierzących”. Interesujących danych, tym razem dotyczących communicantes, dostarczają badania prowadzone przez ISKK. Wartość tego wskaźnika, procentowo odzwierciedlającego stosunek wiernych przystępujących do komunii świętej do ogółu osób do tego uprawnionych, nie podlega większym zmianom od końca lat 90. ubiegłego wieku. Dobrze to widać na rysunku 2. Najniższą wartość communicantes zaobserwowano w 1980 roku (7,8\%), najwyższą zaś w $2000(19,4 \%)$. Za to średnia wartość tego wskaźnika wynosiła w latach 80. - 9,4\%, w 90. - 14,1\%, w pierwszej dekadzie XXI wieku - 16,8\%, a w drugiej - 16,5\%. 


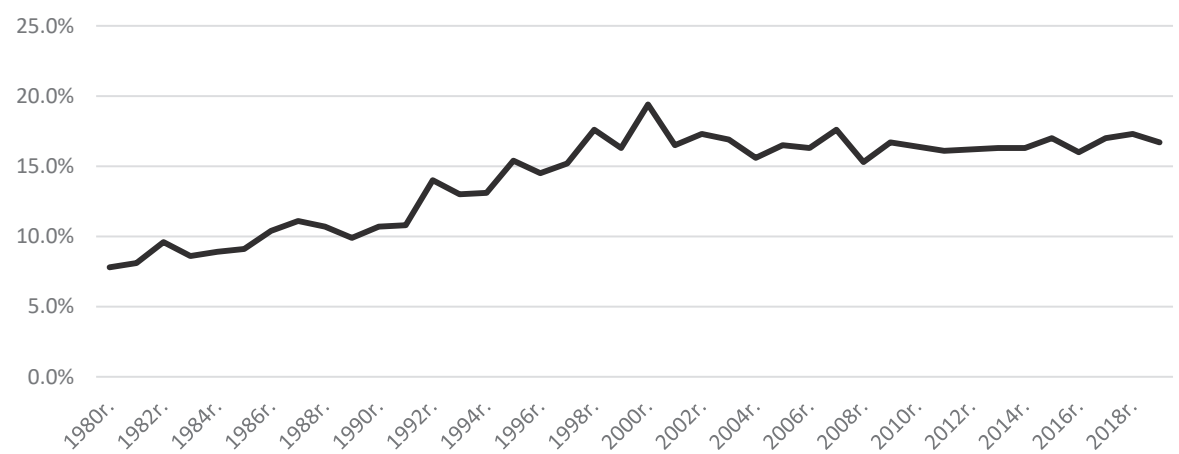

Rysunek 2. Wartości communicantes w latach 1980-2019 [\%]

Źródło: na podstawie danych pochodzących z Instytutu Statystyki Kościoła Katolickiego (http://iskk.pl)

Dane te pokazują, że zdolność Kościoła do organizacji życia religijnego słabnie, ale zapewne tylko (bądź głównie) w przypadku określonego segmentu wiernych. Zarówno z przeprowadzonych przeze mnie analiz, jak i z innych badań wynika, że są to przede wszystkim osoby młodsze, lepiej wykształcone, zamieszkujące duże miasta (zob. Boguszewski i Bożewicz, 2019; Mariański, 2013). Podobne wnioski wyłaniają się też z modelu zaproponowanego przez Gaskinsa, Goldera i Siegela (2013). Z założenia o substytucyjności dóbr świeckich i religijnych wyciągają oni wniosek, że zaangażowanie na rzecz osiągania dóbr religijnych zmniejsza się w warunkach sprzyjających dostępowi do dóbr świeckich. Zawsze istnieją jednak grupy, których możliwości w zakresie osiągania dóbr świeckich są mniejsze. Dla nich (np. dla osób starszych czy słabiej wykształconych) funkcjonowanie w obrębie instytucji religijnych dalej będzie istotne. Co więcej, powinny istnieć także grupy, dla których satysfakcja z uzyskiwania kolejnego dobra świeckiego maleje (zgodnie z funkcją użyteczności krańcowej). A zatem pośród osób zainteresowanych dobrami religijnymi zapewne są też reprezentanci zbiorowości materialnie uprzywilejowanych (choć nie wiadomo, czy chcą oni, aby ich życie religijne było organizowane w ramach Kościoła).

Opisany przeze mnie mechanizm przyczynowy ma więc ograniczoną zdolność wyjaśniającą. Choć wraz z postępującą indywidualizacją jego znaczenie może wzrosnąć, to obecnie dotyczy on tylko części wiernych. Jego obecność prowadzi jednak do sformułowania istotnego pytania: czy Kościół nie powinien zreformować swojego funkcjonowania i spróbować przyciągnąc do siebie tych oddalających się od niego wiernych? Próbując na nie odpowiedzieć, trudno nie zgodzić się z Mariańskim, który pisze: „Nie negując pewnych osiągnięć w pracy Kościoła wynikających z przyjęcia »mentalności konkurencyjnej«, trzeba krytycznie zauważyć, że nie można do końca ujmować spraw religijnych w kategoriach usługowych, rynkowych. Jeżeli nawet w życiu codziennym są takie sfery działania, które wymykają się logice podaży i popytu oraz mentalności rynkowej, to tym bardziej dotyczy to sfery religijnej, duchowej" (Mariański, 2004, s. 75). Ponadto na istotne zjawisko zwrócili uwagę przedstawiciele teorii podażowej. Zakładając istnienie określonych nisz w obrębie rynku religijnego, doszli do wniosku, że instytucje religijne, regulując poziom swojej restrykcyjności mogą 
zyskiwać wiernych (stając się umiarkowane) bądź ich tracić (przemieszczając się do nisz bardziej restrykcyjnych bądź liberalnych) (Iannaccone, 1994; Scheitle, 2007; Stark i Finke, 2000). Dlatego istnieje ryzyko, że dopasowanie się do „migrujących” z Kościoła bardziej liberalnych wiernych nie powstrzymałoby tego procesu, a jedynie wzbudziłoby niepokój i/lub niezadowolenie wśród tych, których związki z tą instytucją pozostają silne. Być może Kościół przyszłości to Kościół mniejszy pod względem liczby wiernych, ale za to wierni ci będą bardziej zaangażowani religijnie.

Na koniec warto omówić pewne ograniczenia związane z badaniem. Po pierwsze, mechanizm przyczynowy stanowiący przedmiot mojego zainteresowania tylko w części wyjaśnia rozważane przemiany religijności. Dotyczy tych wiernych, którzy pod wpływem zachodzących zmian społecznych w coraz mniejszym stopniu znajdują dla siebie miejsce w Kościele. Co jednak z wiernymi, których zachowań ten mechanizm nie wyjaśnia? Czy są to osoby, których proces indywidualizacji nie dotyka? A może reagują na niego w odmienny sposób, jeszcze mocniej zwracając się w stronę religii i Kościoła? Bez względu na to, jakie zjawiska się za tym kryją, konieczne wydaje się opracowanie bardziej ogólnego modelu, uwzględniającego obie te, jakże jednak odmienne, sytuacje. Po drugie, pewnym ograniczeniem niniejszej analizy były same sondaże, a dokładniej rzecz ujmując, obecne w nich pytania. Choć Europejskie Badanie Wartości daje możliwość dokonywania analiz porównawczych, dzięki którym można zestawić ze sobą wyniki pochodzące z różnych krajów, to niektóre, obecne w nim pytania wydają się dość ogólne. Dobrze widać to na przykładzie zmiennej „niezadowolenie z funkcjonowania Kościoła”. Opierała się ona na pytaniu, które można pogłębić (choć zarazem mam świadomość, że takie pogłębienie jest trudne w badaniu ilościowym, w którym podejmuje się wiele różnych zagadnień). Po trzecie, oba uwzględnione przeze mnie sondaże to przykłady badań przekrojowych. Trudno jest zatem na ich podstawie formułować wnioski na temat zachodzących trendów.

\section{PODSUMOWANIE}

Punktem wyjścia dla rozważań podjętych w artykule była teza, zgodnie z którą instytucje religijne tracą zdolność do organizacji życia religijnego swych wiernych. Teorie popytowe, próbując wyjaśnić to zjawisko, skupiają się na czynnikach egzogennych wobec instytucji religijnych, sugerując, że w społeczeństwie zachodzą przemiany skutkujące słabnięciem religii w ogóle. Z kolei teorie podażowe koncentrują się na czynnikach endogennych. Wskazują, że słabnąca zdolność instytucji religijnych do organizacji życia religijnego wiernych - o ile w ogóle występuje - wynika z rozdźwięku między ich „ofertą” a oczekiwaniami wiernych.

Próbując ustosunkować się do tej dyskusji, przyjąłem stanowisko, które określane jest mianem pomostowego, czerpiące zarówno z teorii popytowych, jak i podażowych. Założyłem, że za tą słabnącą zdolnością instytucji religijnych do organizacji życia religijnego leży określony mechanizm przyczynowy. Przeobrażeniom społecznym (przejawiającym się w indywidualizacji życia i wzroście zamożności) towarzyszy zmiana oczekiwań wiernych względem instytucji. Te zaś nie mogąc bądź nie chcąc im sprostać, zniechęcają ich w końcu do siebie. Spróbowałem zweryfikować to założenie, opierając się na danych dotyczących polskich katolików. Analiza potwierdziła obecność rozważanego przeze mnie mechanizmu 
w odniesieniu do części wiernych. Istnieją jednak takie ich segmenty, w których religijność pomimo zachodzących w Polsce zmian - dalej skutecznie jest organizowana w ramach Kościoła. Uzasadnione wydaje się zatem poszukiwanie i opracowanie modelu bardziej ogólnego, umożliwiającego uwzględnienie obu tych odmiennych jednak zjawisk.

\section{BIBLIOGRAFIA}

Baniak, J. (2015). Kościół instytucjonalny w Polsce w wyobrażeniach i ocenach młodzieży licealnej i akademickiej: od akceptacji do kontestacji. Konteksty Społeczne, 1, 5, 27-54.

Berger, P. (2005). Święty baldachim. Elementy socjologicznej teorii religii. Kraków: Zakład Wydawniczy Nomos.

Berger, P. (1999). The Desecularization of the World: Resurgent Religion and World Politics. Washington: Ethics and Public Policy Centre.

Boguszewski, R., Bożewicz, M. (2019). Religijność i moralność polskiej młodzieży - zależność czy autonomia?. Zeszyty Naukowe KUL, 4, 248, 31-51.

Bourdieu, P. (2007). Szkic teorii praktyki, poprzedzony trzema stadiami na temat etnologii Kabylów. Kęty: Wydawnictwo „Antyk”.

Bourdieu, P. (1990). In other words: Essays Towards a Reflexive Sociology. Stanford: Stanford University Press.

Bruce, S., Glendenning, T. (2003). Religious Beliefs and Differences', W: C. Bromley, J. Curtice, K. Hinds, A. Park (red.). Devolution - Scottish Answers to Scottish Questions? Edinburgh: Edinburgh University Press.

Bruce, S., Voas, D. (2010). Vicarious Religion: An Examination and Critique. Journal of Contemporary Religion, 25, 2, 243-259.

Bruce, S. (2016). The sociology of late secularization: social divisions and religiosity, The British Journal of Sociology, 67, 4, 613-631.

Casanova, J. (2005). Religie publiczne w nowoczesnym świecie. Kraków: Zakład Wydawniczy Nomos.

Dhima, K., Golder, M. (2020). Secularization Theory and Religion. Politics and Religion, 1-17.

Finke, R., Stark, R. (2001). The New Holy Clubs: Testing Church-to-Sect Propositions, Sociology of Religion, 2, 62, 175-189.

Gaskins, B., Golder, M., Siegel, D.A. (2013). Religious participation and Economic Conservatism, American Journal of Political Science, 4, 57, s. 823-840.

Heelas, P., Woodhead, L., (2005). The Spiritual Revolution: Why Religion is Giving Way to Spirituality. Oxford: Blackwell.

Iannaccone, L. (1994). Why Strict Churches Are Strong?, American Journal of Sociology, $5,99,1180-1211$.

Inglehart, R., Norris, P. (2006). Sacrum i profanum. Religia i polityka na świecie. Kraków: Zakład Wydawniczy Nomos.

Inglehart, R., Norris, P. (2007). Why Didn't Religion Disappear? Re-Examining Secularization Thesis. W: H. Anheier, Y.R. Isar (ed.). Cultures and Globalization: Conflict and Tensions. London: Sage.

Komunikat CBOS nr 63. (2020). Religijność Polaków w ostatnich 20 latach. 
Kopka, J. (2014). Moralność ratunkiem czy przeszkodą dla współczesnego człowieka? Opis stanu i analiza przemian. Folia Sociologica, 48, 35-51.

Libiszowska-Żółtkowska, M. (2010). Dlaczego odchodzą? Studenci mówią „nie” Kościołowi katolickiemu. Analiza wyników badań empirycznych. Annales. Universitatis Mariae Curie-Skłodowska, 25, 121-134.

Luckmann, T. (1990). Shrinking Transcendence, Expanding Religion?, Sociological Analysis, 51, 2, 127-138.

Luckmann, T. (2006). Niewidzialna religia. Problem religii we współczesnym świecie. Kraków: Zakład Wydawniczy Nomos.

Luhmann, N. (2007). Funkcje religii. Kraków: Zakład Wydawniczy Nomos.

Mariański, J. (2004). Co mówi „duch czasu” - sekularyzacja religii i społeczeństwo postsekularne. Roczniki Nauk Społecznych, 321, 49-83.

Mariański, J. (2008). Tożsamości religijne w społeczeństwie polskim. W: I. Borowik, M. Libiszowska-Żółtkowska, T. Doktór (red.). Oblicza religii i religijności. Kraków: Zakład Wydawniczy Nomos.

Mariański, J. (2010). Religia w społeczeństwie ponowoczesnym. Warszawa: Wydawnictwo Oficyna Naukowa.

Mariański, J. (2013). Podstawowe pojęcia socjologii religii w eksplikacji ks. Janusza Mariańskiego. Lublin: Wydawnictwo Polihymnia.

Mariański, J. (2013). Sekularyzacja - desekularyzacja - nowa duchowość. Studium Socjologiczne. Kraków: Zakład Wydawniczy Nomos.

Mariański, J. (2017). Autorytet społeczny Kościoła katolickiego w Polsce w procesie przemian. Studia Paedagogica Ignatiana, 20, 5, 77-106.

Scheitle, C.P. (2007). Organizational Niches and Religious Markets: Uniting Two Literatures. Interdisciplinary Journal of Research on Religion, 3, 1-29.

Stark, R., Finke, R. (2000). Acts of Faith: Explaining the Human Side of Religion. Berkeley: University of California Press.

Stark, R., Finke, R.. (2000). Acts of Faith: Exploring the Human Side of Religion. Berkeley: University of California Press.

Stark, R., Iannaccone, L. (1994). A Supply-Side Reinterpretation of the "Secularization" of Europe. Journal for the Scientific Study of Religion, 3, 33, 230-252.

Stark, R., Iannaccone, L. (1995). Pluralism and Piety: England and Wales, 1851, Journal for the Scientific Study of Religion, 4, 34, 431-444.

Stark, R., Smith, B.G. (2010). Conversion to Latin American Protestantism and the Case of Religious Motivation. Interdisciplinary Journal of Research on Religion, nr 6, 1-17.

Stark, R. (1999). Secularization, R.I.P. Sociology of Religion, 3, 60, 249-273.

Voas, D., Bruce, S. (2007). The Spiritual Revolution: Another False Down for the Sacred. W: K. Flanagan, P.C. Jupp (ed.). Sociology of Spirituality. Farnham: Ashgate.

Zielińska, K. (2009). Spory wokót sekularyzacji. Kraków: Zakład Wydawniczy Nomos.

\section{Bazy danych}

Europejskie Badanie Wartości, http://europeanvaluesstudy.eu

ISKK: Instytut Statystyki Kościoła Katolickiego SAC im. Ks. Witolda Zdaniewicza, http:// issk.pl 
THE CRISIS OF RELIGIOUS INSTITUTIONS AND ITS IMPACT ON RELIGIOSITY. THE CASE OF POLAND

It would be valuable on the basis of sociology religion to concentrate on the crisis of religious institutions and its impact on religiosity in the contemporary sociological discussions. According to theories of secularization, the crisis is a symptom of a broader process of secularization and it is related to the structural changes. In turn, the economic theories assume the crisis as a consequence of some non-effectiveness of religious institutions to the needs of the believers. Both approaches seem to provide interesting solutions to the problem. Here, I took a midway position I found that the structural changes decrease the ability of religious institutions to organize religious life of its members and, in result, the members are less and less satisfied with them. In addition, this process has its own impact on their religiosity. The main consequence of the crisis is the decline in church attendance. In order to verify the assumptions I used the data on Polish Catholics from two surveys carried out in 1999 and 2008 as the part of the European Values Servey. The outcomes of the statistical analysis seem to confirm the above assumptions.

Keywords: deinstitutionalization of religion, Catholic Church, religiosity, secularization, European Values Study

Zgłoszenie artykułu: 20.01.2021

Recenzje: 17.02 .2021

Rewizja: 15.03 .2021

Akceptacja: 16.03 .2021

Publikacja on-line: 30.09 .2021

(C) 2021 Autor. Jest to publikacja ogólnodostępna, którą można wykorzystywać, rozpowszechniać i kopiować w dowolnej formie zgodnie z licencją Creative Commons CC-BY 4.0 